\title{
Stiff Sunflower Population Dynamics on Summer-grazed Sandhills Rangeland
}

\author{
Patrick E. Reece, Walter H. Schacht, and Ann E. Koehler \\ Authors are ${ }^{1}$ Professor, University of Nebraska, Panhandle Research and Extension Center, 4502 Ave I, Scottsbluff, NE 69361; \\ ${ }^{2}$ Associate Professor, Dept of Agronomy, 347 Keim Hall, Lincoln, NE 68583; and ${ }^{3}$ Research Analyst, Panhandle Research and \\ Extension Center, 4502 Ave I, Scottsbluff, NE 69361.
}

\begin{abstract}
Thousands of forb species are distributed among the diverse rangelands of North America. However, little is known about livestock grazing effects on the demographics and potential demise of palatable forbs in grassland ecosystems. A study was designed to quantify the cumulative effects of summer grazing on the demographics of stiff sunflower (Helianthus rigidus [Cass.] Desf. spp. subrhomboides [Rydb.] Heiser), a highly palatable, late-seral, perennial forb. Pastures were grazed for 5-7 days in mid-June or midJuly during 1995-1997 at 16,32, or 48 animal unit days (AUD) per hectare. All grazing treatments reduced the plant height of stiff sunflower. However, population densities were maintained throughout the study at light stocking rates ( $16 \mathrm{AUD}^{\circ} \mathrm{ha}^{-1}$ ). In contrast, a single year of heavy stocking ( $48 \mathrm{AUD} \cdot \mathrm{ha}^{-1}$ ) in June reduced spring stiff sunflower densities $55 \%$. Densities declined about $30 \%$ after 1 year at moderate stocking rates $\left(32 \mathrm{AUD} \cdot \mathrm{ha}^{-1}\right)$ in either month or heavy stocking in July. After 3 years of short-duration grazing in June, moderate and heavy stocking rates eliminated some colonies and reduced mean pasture densities by about $90 \%$ compared with $40 \%$ and $70 \%$ reductions in moderately and heavily stocked July-grazed pastures, respectively. Reductions in spring densities corresponded to increases in premature senescence the previous year when more than $30 \%$ of the plants turned brown before mid-August. Critical levels of premature senescence were likely to occur when more than $60 \%$ of stiff sunflower plants within colonies were grazed. Light stocking rates are rare on privately owned Nebraska Sandhills rangeland ( 4.7 million ha); therefore, vigorous populations of stiff sunflower are most likely to occur in pastures used predominantly during the dormant season.
\end{abstract}

\section{Resumen}

Miles de especies de forraje están distribuidas entre el diverso campo de Norteamérica. Sin embargo, poco se sabe acerca del efecto del pastoreo ganadero en la demografía y posible fallecimiento de forraje aceptable en ecosistemas de pradera. Este estudio fue designado para cuantificar los efectos cumulativos del pastoreo en el verano en la demografía del girasol (Helianthus rigidus [Cass.] Desf. spp. subrhomboides [Rydb.] Heiser), una sumamente aceptable, tardía planta perenne. Las praderas fueron pastoreadas por 5-7 días en la mitad de junio o mitad de julio durante 1995-1997 en 16,32, o 48 unidades de días con animales (AUD) por hectárea Todos los tratamientos de pastoreo redujeron la estatura del girasol. Sin embargo, la densidad de la populación se mantuvo en un índice de abastecimiento liviano $\left(16 \mathrm{AUD}^{\bullet} \mathrm{ha}^{-1}\right)$. En contraste, un solo año de abastecimiento pesado (48 AUD•ha ${ }^{-1}$ ) en junio redujo la densidad del girasol en la primavera a $55 \%$. La densidad desminuyo como $30 \%$ despues del 1 año en un índice de abastecimiento moderado $\left(32 \mathrm{AUD} \mathrm{ha}^{-1}\right.$ ) en cualquier mes o abasteciemiento pesado en julio. Despues de 3 años de pastoreo a corto plazo en junio, el índice de abastecimiento moderado y pesado eliminaron algunas de las colonias y redujeron el promedio de la densidad de la pastura por $90 \%$ comparado con $40 \%$ y $70 \%$ de reducción en el abastecimiento del pastoreo moderado y pesado en julio, respectivamente. La reducción en la densidad primaveral corresponde al aumento en senectud prematura el año anterior cuando más de $30 \%$ de las plantas se pusieron café antes de la mitad de agosto. Niveles criticos de senectud prematura probablemente ocurrio cuando más de $60 \%$ de las plantas de girasol dentro de las colonias fueron pastoreadas. Indices de abastecimiento liviano son poco común en campos privadas en las Sandhills de Nebraska (4.7 millones ha); por lo tanto, la populación vigorosa de girasol es más probable que ocurran en pastos usados predominantemente durante la estación latente.

Key Words: Helianthus rigidus ssp. subrhomboides, plant size and density, grazing tolerance, defoliation characteristics, summer mortality, cumulative grazing pressure

\section{Introduction}

Some forbs are valuable sources of nutrients for vertebrate (Hoehne et al 1968; Hodgkinson 1980; Pieper and Beck 1980; Cook 1983; Holechek 1984; Arthun et al 1992; Hartnett 1996;

Research was partially funded by the Anna $\mathrm{H}$. Elliott Fund, University of Nebraska Foundation. Published as Paper 13417, Journal Series, Nebraska Agricultural Research Division.

Correspondence: Dr Patrick E. Reece, University of Nebraska, Panhandle Research and Extension Center, 4502 Ave I, Scottsbluff, NE 69361. Email: preece@unl.edu
Frankland and Nelson 2003) and invertebrate (Dickinson and McKone 1992) herbivores. Assessment of range condition is based generally on composition of graminoid species with little weight placed on native perennial forbs (Holechek 1984; Nichols and Jensen 1998). Consequently, highly palatable, late-seral forb species can be eliminated from plant communities with little or no change in range condition scores and recommended stocking rates. Published studies of defoliation effects on vigor and/or population dynamics of forb species are uncommon (Julander 1968; Laycock and Conrad 1969; Inouye 1982; Reichman and Smith 1991; Gronemeyer et al 1997) and rare for forbs in grass-dominated ecosystems (Hartnett 1990;

Manuscript received 1 June 2001; manuscript accepted 6 June 2004 
Vermeire and Gillen 2000; Damhoureyeh and Hartnett 2002; Hickman and Hartnett 2002).

Stiff sunflower (Helianthus rigidus [Cass.] Desf. ssp. subrhomboides [Rydb.] Heiser.) is a single-stemmed, highly palatable, late-seral, perennial forb with a pseudo-annual life cycle (Kawano 1985). A pseudo-annual is a perennial plant that behaves as a vegetatively propagating annual (Verburg et al 1996). Parent plants die at the end of each growing season. Next year's population originates from hibernacles that develop at the distal ends of preceding-year rhizomes. Inherently high

tein content of seeds and resistance to pathogens have ulted in the agronomic use of this native sunflower by plant breeders to enhance commercial sunflower seed production (Atlagić 1996; Verburg et al 1996). Stiff sunflower is widely distributed in the northern Great Plains of the United States and Canada (Great Plains Flora Association 1986), but generally accounts for less than $5 \%$ of total annual herbage production.

This study was initiated when yearling cattle demonstrated relatively high preferences for stiff sunflower during the first year of a 3-year summer grazing study (Cullan et al 1999) at the University of Nebraska-Lincoln, Gudmundsen Sandhills Laboratory. The purpose of our study was to quantify the cumulative effects of 3 years of summer grazing on stiff sunflower population dynamics. Given the relatively high palatability of this species, we hypothesized that 1) large declines in population densities would occur after 3 years of summer grazing, regardless of cumulative grazing pressure; and 2) population densities and plant vigor would decline concurrently.

\section{Materials and Methods}

The study was conducted on sands range sites in good to excellent condition at the University of Nebraska, Gudmundsen Sandhills Laboratory $\left(42^{\circ} 07^{\prime} \mathrm{N}, 101^{\circ} 43^{\prime} \mathrm{W}\right.$, elevation $\left.1049 \mathrm{~m}\right)$ located near Whitman, Nebraska. Prairie sandreed (Calamovilfa longifolia [Hook.] Scribn.), sand bluestem (Andropogon hallii Hack.), little bluestem (Andropogon scoparius Michx.), and switchgrass (Panicum virgatum L.) composed about $63 \%$ of peak standing herbage (Northup 1993). Plant nomenclature follows the Great Plains Flora Association (1986). Twenty additional graminoid species accounted for $23 \%$ of peak standing herbage, and 54 species of forbs, succulents, and shrubs accounted for the remaining $14 \%$. Composition of stiff sunflower was less than $2 \%$ in all pastures. Soils were Valentine fine sands (mixed, mesic Typic Ustipsamments).

Precipitation and air temperature data were measured and recorded by an automated weather station at the laboratory headquarters. These data were used to determine plant-year precipitation, the moisture potentially available to plants during the growing season. It includes precipitation received during the preceding dormant season (October-March) plus that received during the current growing season (April-September). Plant year is identified by the year of the active growing season. The 13-year average annual precipitation is $45 \mathrm{~cm}$.

Experimental units were individual 1.0 -ha pastures. Twentyone pastures were separated into 3 blocks based on similar frequencies of plant species occurrence in fifty $0.25-\mathrm{m}^{2}$ square quadrats $(50 \times 50 \mathrm{~cm})$ randomly located in uniformly spaced belt transects in each pasture during May 1995. Occurrence of hairy grama (Bouteloua hirsuta Lag.), little bluestem, prairie sandreed, and sand bluestem was recorded in $0.01-\mathrm{m}^{2}$ and $0.05-\mathrm{m}^{2}$ areas nested within the $0.25-\mathrm{m}^{2}$ quadrats. Seven grazing treatments were randomly allotted to pastures within each block. Treatments consisted of light (16), moderate (32), or heavy (48 animal unit days [AUD] $h^{-1}$ ] grazing for 5-7 days in mid-June or mid-July, and a nongrazed control. Grazing treatments were applied to the same pastures each summer from 1995 through 1997. Yearling cattle were weighed after an overnight stand without food and water and allocated to treatments to provide equal total cattle weights for replications within stocking rate treatments. The number of yearlings per pasture ranged from 4 to 12 . All pastures were rested in 1992 and 1994 and stocked at 49 AUD $\cdot h^{-1}$ from June to October 1993.

Before grazing treatments were applied, current-year standing herbage was estimated by clipping all vegetation at ground level in 10 randomly located $0.25-\mathrm{m}^{2}$ rectangular quadrats $(25 \times 100 \mathrm{~cm})$ per pasture. Based on repeated observations in these pastures during a previous study, Northup (1993) reported that six-week fescue (Festuca octoflora Walt.), green sagewort (Artemisia dracunculus L.), western ragweed (Ambrosia psilostachya DC.), prickly pear (Opuntia spp. P. Mill.), pincushion cactus (Coryphantha vivipara [Nutt.] Britt. and Rose), and prairie wild rose (Rosa arkansana Porter) were not grazed or were rarely grazed by cattle in June or July. These species and all previous year's growth were discarded. The remaining herbage was oven dried at $60^{\circ} \mathrm{C}$ for 48 hours and weighed to determine dry matter yield. Grazing pressure was expressed as AUDs per metric ton of current-year palatable herbage (AUD $\cdot \mathrm{Mg}^{-1}$ ) measured at the beginning of grazing periods.

Stiff sunflower colonies were mapped during a walking reconnaissance through the pastures, and 8 of the colonies were randomly selected in each pasture in August 1995. One 2.25$\mathrm{m}^{2}$ quadrat $(1.5 \times 1.5 \mathrm{~m})$ was placed near the center of each selected colony, and its location was permanently marked with wooden survey stakes. Total number of live and dead stiff sunflower plants were counted in the quadrats in all pastures during the second week of August 1995 through 1997. Stubble height of each grazed stiff sunflower plant was measured in all quadrats immediately after grazing in June or July 1996 and 1997. Preliminary data for grazing effects on stiff sunflower in 1995 included stubble height of grazed plants measured during the second week of August. To determine the cumulative effects of grazing treatments, we measured height of each sunflower plant as an index of vigor and sunflower density during the second week of June 1996 through 1998, before grazing occurred each year.

When grazed by beef cattle, stiff sunflower stems frequently break between leaf nodes, leaving intact leaves at the highest remaining nodes. All stiff sunflower plants inside twenty $0.5-\mathrm{m}^{2}$ quadrats $(71 \times 71 \mathrm{~cm})$ randomly located in nongrazed areas adjacent to study pastures were clipped at ground level during June and July 1996 and 1997. To estimate the relationship between percentage of leaf area removed and stubble height, we measured surface area of leaves with a Licor laboratory leaf area meter and recorded height of nodes from which each leaf originated for each individual in these collections. Nonlinear inverse polynomial equations were fit to these data $(P<0.0001)$ and used to estimate percentage of leaf area 
Table 1. Height of stiff sunflower shoots in late spring for nongrazed pastures and after 1 (1996), 2 (1997), and 3 years (1998) of short duration grazing treatments at 16,32 , or $48 \mathrm{AUD} \cdot \mathrm{ha}^{-1}$ averaged over mid-month grazing dates.

\begin{tabular}{|c|c|c|c|}
\hline \multirow{2}{*}{$\begin{array}{l}\text { Stocking rate } \\
\left(\text { AUD } \operatorname{ha}^{-1}\right)\end{array}$} & \multicolumn{3}{|c|}{ Mean shoot height ${ }^{1}$} \\
\hline & $1996(\mathrm{~cm})$ & $1997(\mathrm{~cm})$ & $1998(\mathrm{~cm})$ \\
\hline 0 & $11.8^{\mathrm{cd}}$ & $14.0^{\mathrm{ab}}$ & $15.2^{a}$ \\
\hline 16 & $10.1^{\mathrm{ef}}$ & $11.8^{\text {cd }}$ & $12.8^{b c}$ \\
\hline 32 & $10.1^{\mathrm{ef}}$ & $11.2^{\text {de }}$ & $10.3^{\text {ef }}$ \\
\hline 48 & $8.8^{9}$ & $9.5^{\mathrm{fg}}$ & $8.5^{9}$ \\
\hline
\end{tabular}

'Means followed by the same letter are not significantly different, $P>0.05$. Standard errors for individual means ranged from 0.1 to $0.9 \mathrm{~cm}$. Year by stocking rate interaction effects were significant at $P<0.04$.

removed from the mean stubble height of grazed plants in each pasture. Standard errors of slope coefficients for the nonlinear equations ranged from $3 \%$ to $5 \%$ of coefficient values.

The $2 \times 3$ factorial array of grazing dates and stocking rates produced a wide range in cumulative grazing pressure. Linear, PROC REG (SAS 2002), or nonlinear, PROC NLIN (Ratkowsky 1990; SAS 2002) regression procedures and mean values for pastures were used to estimate the effects of cumulative grazing pressure on percentage of leaf area removed from grazed plants and percentage change in green shoots from June to August 1996 and 1997. A mixed model procedure, PROC MIXED (SAS 2002), was used to determine summer grazing effects on percentage of stiff sunflower shoots grazed in June or July in 1995, 1996, and 1997 and mean population density and plant height in the second week of June after 1 (1996), 2 (1997), and 3 years (1998) of grazing. The Least-Squares Means Procedure (SAS 2002) was used for mean separation among grazing treatments. Treatment effects were considered significant at $\mathrm{P} \leq 0.05$ unless otherwise stated.

Stiff sunflower plants in adjacent nongrazed areas were excavated to a depth of $20 \mathrm{~cm}$ biweekly from mid-May to midAugust 1997 to provide qualitative information on seasonal patterns in rhizome dynamics. Twenty-eight $0.5-\mathrm{m}^{2}$ plots $(71 \times 71 \mathrm{~cm})$ were marked with wooden survey stakes and randomly allotted to excavation dates at each of 3 locations. Preceding-year rhizomes were absent or nearly decomposed when plants began to develop rhizomes in mid-June. Although similar in diameter $(1-4 \mathrm{~mm})$ and color to primary roots, rhizomes were circumscribed by fused pairs of bracts, visible with a $\times 5$ lens, at 15 - to 60 -mm intervals.

\section{Results and Discussion}

\section{Shoot Height and Density Relationships}

Cumulative effects of summer stocking rates on height of stiff sunflower shoots in late spring after 1,2, and 3 years of grazing treatments were similar for June- and July-grazed pastures. Late spring plant height increased from 1996 to 1998 in nongrazed and lightly stocked pastures (Table 1) despite below-average plant-year precipitation for the 1996 and 1997 growing seasons (Fig. 1). Monthly values of cumulative precipitation were $42 \%-$ $67 \%$ above average during the 1995 growing season (May to September), $10 \%-21 \%$ below average during $1996,19 \%-43 \%$

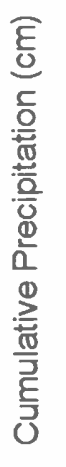

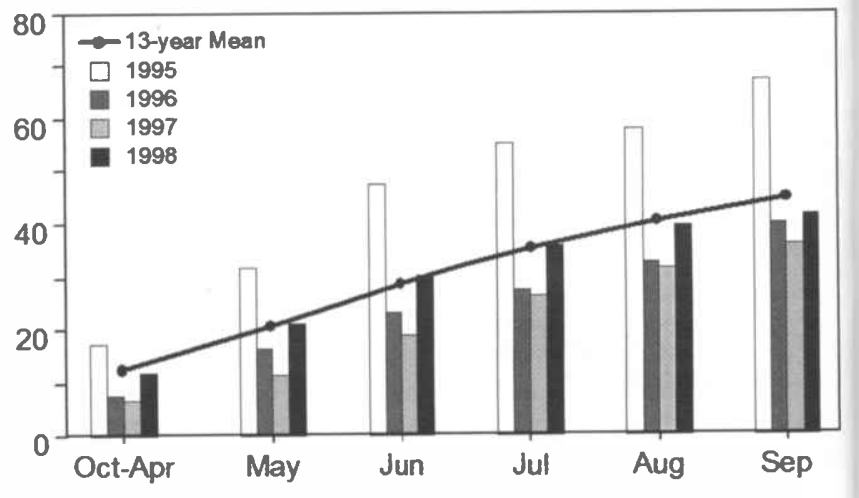

Figure 1. Cumulative plant-year precipitation, October-September, for the 1995-1998 growing seasons and the 1987-1999 average at the University of Nebraska-Lincoln, Gudmundsen Sandhills Laboratory near Whitman, Nebraska.

below average during 1997, and near average during 1998. Increases in stiff sunflower plant height in nongrazed or lightly stocked pastures during years with progressively less precipitation indicated this species is competitive with associated species when selective herbivory is limited. Plant height was similar for light $\left(16 \mathrm{AUD} \cdot \mathrm{ha}^{-1}\right)$ and moderate stocking (32 AUD•ha ${ }^{-1}$ ) after 1 and 2 years of grazing (Table 1). After 3 years of grazing, late spring plant height in moderately stocked pastures was $23 \%$ less than lightly stocked pastures and $33 \%$ less than nongrazed pastures. Heavy stocking reduced late spring height to a plateau of about $9 \mathrm{~cm}$, which was $75 \%, 68 \%$, and $56 \%$ of the mean nongrazed population plant height after 1,2 , and 3 years of grazing, respectively.

Density of stiff sunflower shoots inside permanently marked quadrats was stable throughout the study in nongrazed and lightly stocked pastures (Fig. 2), averaging 20 plants $\bullet \mathrm{m}^{-2}$, regardless of precipitation regime (Fig. 1) and/or month of grazing. Therefore, we reject our hypothesis that relatively large declines in population densities will occur after 3 years of grazing during June or July regardless of cumulative grazing pressure. In contrast, late spring populations were reduced by about $30 \%$ after 1 year of moderate stocking in June or July or heavy stocking in July compared with a $55 \%$ reduction after 1 year of heavy stocking in June (Fig. 2). Relatively large population declines after a single year of grazing when cumulative precipitation was $60 \%$ above average indicated a relatively low tolerance to summer grazing at traditional stocking rates. After 3 years of moderate or heavy grazing in June, some stiff sunflower colonies were eliminated, and mean pasture densities were reduced by about $90 \%$ compared with $40 \%$ and $70 \%$ reductions in moderately and heavily stocked July-grazed pastures, respectively. In contrast, in a tallgrass prairie in Kansas moderate to heavy cattle grazing reduced shoot growth and/or sexual reproduction but did not change the abundance of 3 palatable forbs, white aster (Aster ericoides L.), fringeleaf ruellia (Ruellia bumilis Nutt.), and lead plant (Amorpha canescens Pursh; Hickman and Hartnett 2002). However, in their study frequency data (collected from different randomly located transects each year) were used as an index of abundance rather than monitoring permanently marked populations of these species. Additionally, greater average annual 


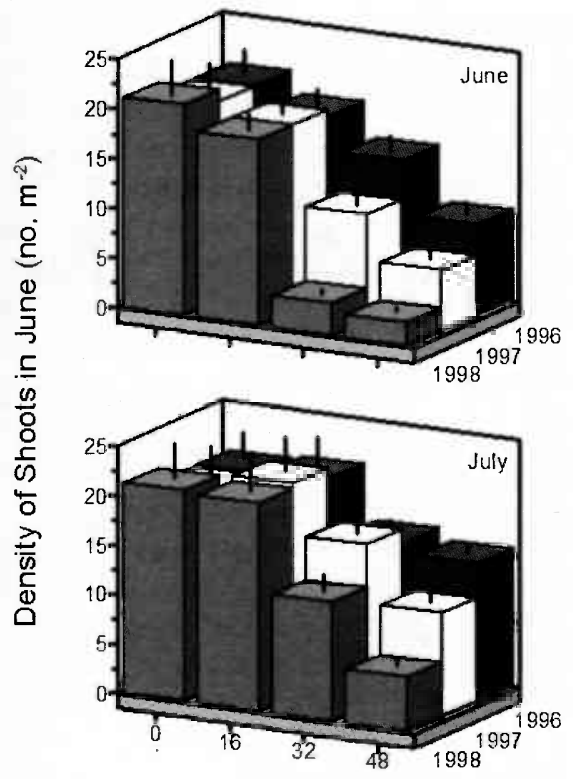

Stocking Rate (AUD ha-1)

Figure 2. Mean stiff sunflower densities during the second week of June after 1,2 , and 3 consecutive years of light (16 AUD•ha ${ }^{-1}$ ), moderate (32 AUD•ha $\left.{ }^{-1}\right)$, and heavy (48 AUD•ha ${ }^{-1}$ ) stocking in mid-June or mid-July and for nongrazed controls in 1996, 1997, and 1998. The year by month by stocking rate interaction was significant at $P<0.002$. Bars represent standard errors.

precipitation at the Kansas study site $(91$ vs $45 \mathrm{~cm}$ at the Gudmundsen Sandhills Laboratory) may have enhanced plant survival and the opportunity for regrowth following grazing.

Declines in stiff sunflower population density may reflect the impact of moderate and heavy grazing on rhizome and hibernacle production. Frankland and Nelson (2002) reported declines in rhizome length of red trillium (Trillium recurvatum Beck) that corresponded to reduced plant height in populations repeatedly grazed by white-tailed deer (Odocoileus virginianus Zimmerman). Additionally, a single year of simulated bison grazing at levels observed in tallgrass prairie pastures in Kansas (Damhoureyeh and Hartnett 2002) reduced rhizome bud initiation in white aster and cudweed sagewort (Artemisia ludoviciana Nutt.). Based on our excavations of nongrazed stiff

Table 2. Percentage of stiff sunflower shoots grazed in June or July in lightly (16 AUD•ha $\left.{ }^{-1}\right)$, moderately (32 AUD・ha-1), or heavily (48 AUD·ha ${ }^{-1}$ ) stocked pastures in 1995, 1996, and 1997 . $^{1}$

\begin{tabular}{|c|c|c|c|c|c|c|}
\hline \multirow{2}{*}{ 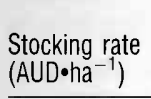 } & \multicolumn{2}{|c|}{1995} & \multicolumn{2}{|c|}{1996} & \multicolumn{2}{|c|}{1997} \\
\hline & June $(\%)$ & July (\%) & June (\%) & July (\%) & June $(\%)$ & July (\%) \\
\hline 16 & $56^{c}$ & $60^{c}$ & $46^{\mathrm{d}}$ & $52^{c d}$ & $99^{a}$ & $87^{\mathrm{ab}}$ \\
\hline 32 & $96^{\mathrm{a}}$ & $75^{\mathrm{bc}}$ & $87^{\mathrm{a}}$ & $69^{b c}$ & $86^{b}$ & $74^{\mathrm{b}}$ \\
\hline 48 & $93^{\mathrm{ab}}$ & $85^{\mathrm{ab}}$ & $91^{\text {á }}$ & $79^{\mathrm{ab}}$ & $77^{\mathrm{b}}$ & $56^{c}$ \\
\hline
\end{tabular}

"Values for 1995 are preliminary data collected during the second week of August. Although these data were collected 1-2 months later than in 1996 and 1997, any impact from defoliation by wildlife during this interval appears to have been minor. Means within years with the same letter are not significantly different, $P>0.05$. Standard errors of individual means ranged from 0.5 to 5.0 percentage points.

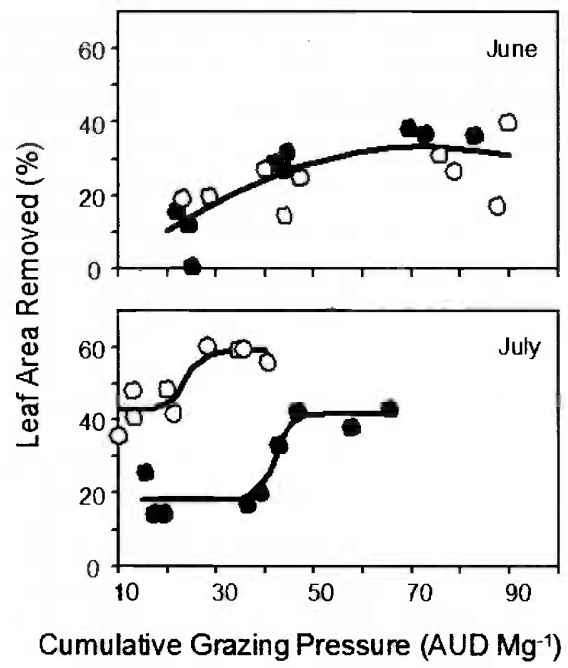

Figure 3. Effects of cumulative grazing pressure on percentage of leaf area removed from stiff sunflower plants during short-duration grazing periods in June or July 1996 (open circle) and 1997 (filled circle). Regression equations are in Table 3.

sunflower plants, the number of rhizomes per plant (0-4) generally increased with plant size, and most rhizome-bearing plants had 5 or more fully expanded pairs of leaves. Stiff sunflower populations in moderately and heavily stocked pastures were skewed toward smaller plants (Table 1) and leaf area replacement after grazing was limited. Therefore, it is likely that the production of rhizomes and hibernacles critical for repopulating stiff sunflower (Westley 1993) was reduced.

The relationship between late spring plant height and plant density was inconsistent. Light stocking rates reduced stiff sunflower plant heights by about $15 \%$ each year compared with nongrazed populations (Table 1), but had no effect on density. Conversely, density was lower in moderately stocked compared with lightly stocked pastures (Fig. 2) with similar plant height (Table 1) after 1 and 2 years of grazing. Plant height declined after 1 year of heavy stocking with relatively little change during the following 2 years (Table 1), whereas shoot density continued to decline each year (Fig. 2). Therefore, we reject our hypothesis that population densities and plant height decline concurrently.

\section{Defoliation Patterns}

The effects of stocking rate on defoliation patterns in 1995 and 1996 were similar (Table 2). During these nondrought years, a relatively high percentage of stiff sunflower plants were ungrazed $(37 \%-54 \%)$ in lightly stocked pastures. In contrast, during 1997, a drought year, cattle grazed nearly all stiff sunflower plants in lightly stocked pastures but removed less than $25 \%$ of the leaf area (Fig. 3). The high percentage of ungrazed plants during 1995 and 1996 and the low level of leaf area removal during 1997 may explain why subsequent-year stiff sunflower density in lightly stocked June- and July-grazed pastures was similar to nongrazed populations (Fig. 2).

After 3 years, the density of stiff sunflowers in moderately stocked June-grazed pastures was not significantly different 
Table 3. Regression equations for the effects of cumulative grazing pressure on the percentage of leaf area removed and the percentage change in the number of live stiff sunflower shoots between early June and mid-August.

\begin{tabular}{|c|c|c|c|}
\hline \multirow[b]{2}{*}{ Grazing date } & \multicolumn{2}{|c|}{ Equation } & \multirow[b]{2}{*}{$P>F$} \\
\hline & Parameter & Standard error & \\
\hline \multicolumn{4}{|c|}{ Leaf area removed (\%) (Fig. 3) } \\
\hline \multirow[t]{4}{*}{ June 1996 and 1997} & \multicolumn{2}{|c|}{$y=\alpha+\beta x+\gamma x^{2}$} & 0.0022 \\
\hline & $\alpha=-11.7892$ & 12.0022 & \\
\hline & $\beta=1.2453$ & 0.5019 & \\
\hline & $\gamma=-0.00862$ & 0.004493 & \\
\hline \multirow[t]{5}{*}{ July 1996} & \multicolumn{2}{|c|}{$y=\delta+\alpha /[1+\exp (\beta-\gamma \times x)]$} & 0.0300 \\
\hline & $\alpha=16.3366$ & 4.1751 & \\
\hline & $\beta=18.5735$ & 39.9212 & \\
\hline & $\gamma=0.7863$ & 1.8660 & \\
\hline & $\delta=42.6697$ & 2.8749 & \\
\hline \multirow[t]{5}{*}{ July 1997} & \multicolumn{2}{|c|}{$y=\delta+\alpha /[1+\exp (\beta-\gamma \times x)]$} & 0.0054 \\
\hline & $\alpha=23.3868$ & 3.7668 & \\
\hline & $\beta=35.9252$ & 33.5790 & \\
\hline & $\gamma=0.8565$ & 0.7909 & \\
\hline & $\delta=17.9756$ & 2.3973 & \\
\hline \multicolumn{4}{|c|}{ Change in density of live shoots from June to August (\%) (Fig. 4) } \\
\hline \multirow[t]{3}{*}{ June 1996} & \multicolumn{2}{|c|}{$y=\alpha+\beta x$} & 0.0310 \\
\hline & $\alpha=-0.72526$ & 9.49455 & \\
\hline & $\beta=-0.41112$ & 0.15272 & \\
\hline \multirow[t]{4}{*}{ June 1997} & \multicolumn{2}{|c|}{$y=\alpha+\beta \times \exp (-\delta \times x)$} & 0.0014 \\
\hline & $x=-85.8390$ & 7.8923 & \\
\hline & $\beta=458.8$ & 402.0 & \\
\hline & $\delta=0.0845$ & 0.0402 & \\
\hline \multirow[t]{3}{*}{ July 1996 and 1997} & \multicolumn{2}{|c|}{$y=\alpha+\beta x$} & $<0.0001$ \\
\hline & $x=9.83075$ & 7.31344 & \\
\hline & $\beta=-1.45110$ & 0.21069 & \\
\hline
\end{tabular}

from zero, whereas stiff sunflower populations in moderately stocked July-grazed pastures maintained $60 \%-80 \%$ of their initial density (Fig. 2). This pattern may have occurred because a higher percentage of stiff sunflower plants were grazed in moderately stocked June-grazed pastures than in July-grazed pastures (Table 2), perhaps reflecting a seasonal decline in relative palatability in July compared with June and the lower cumulative grazing pressure in July (Fig. 3). The percentage of leaf area removed increased measurably from light to moderate stocking in June-grazed pastures (Fig. 3), whereas in Julygrazed pastures the percentage of leaf area removed changed little until relatively high cumulative grazing pressures occurred within each year.

Declines in stiff sunflower density in heavily stocked pastures were greater in June-grazed than in July-grazed pastures (Fig. 2) following similar or lower levels of leaf area removal (Fig. 3). The relatively short height (Table 1) and declining density (Fig. 2) of stiff sunflower plants in heavily stocked pastures indicated a decline in vigor, which may have reduced drought tolerance in 1997.

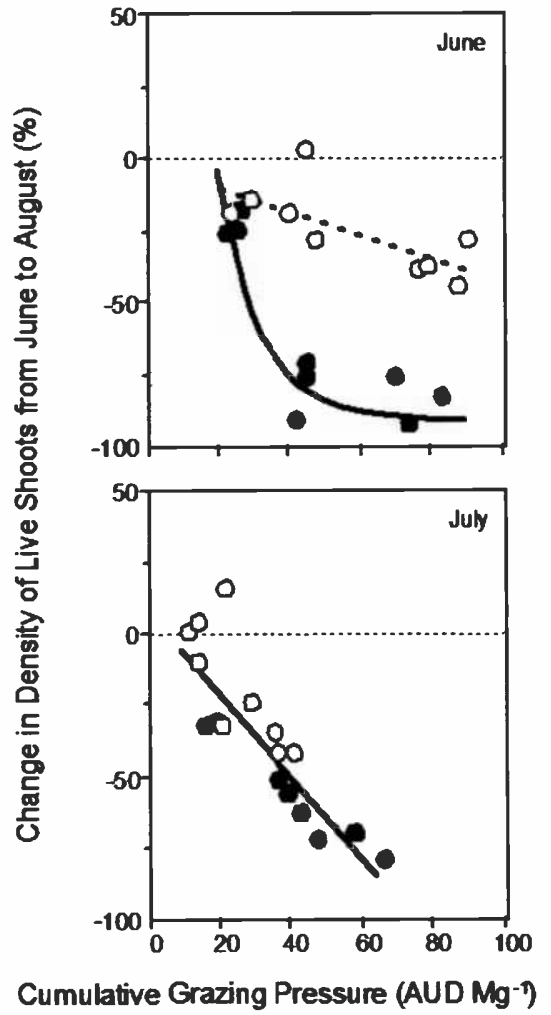

Figure 4. Effects of cumulative grazing pressure on change in density of live stiff sunflower shoots from early June to mid-August in June-grazed and July-grazed pastures during 1996 (open circle) and 1997 (filled circle). Regression equations are in Table 3.

The decline in vigor of stiff sunflowers likely resulted from a loss of leaf area. Little or no leaf area replacement occurred after grazing in June or July regardless of stocking rate or year. Growth from axillary buds was common and included floral bud development, but new leaves were relatively small and little photosynthetically active surface area was replaced by midAugust. Additionally, our estimates of percent leaf area removal may have been conservative because regression equations were based on populations with mixed plant heights, and tall plants were more likely to be grazed than short plants. Given the positive relationship between plant size and number of rhizomes per plant, defoliation of the largest plants could have reduced the ability of stiff sunflower colonies to reproduce. Differences between estimated and actual levels of defoliation diminished as the percentages of plants grazed increased (Table 2).

\section{Premature Senescence}

Ungrazed stiff sunflower plants were green until killing frost in October. Grazing in June or July caused plants to turn brown by mid-August. Live shoot density declined by $11 \%-38 \%$ as cumulative grazing pressure increased in June-grazed pastures in 1996 (Fig. 4). In contrast, grazing-induced premature senescence increased rapidly from $25 \%$ to $80 \%$ in June-grazed pastures when drought occurred in 1997 (Fig. 4). Inconsistent grazing effects over similar levels of grazing pressure between years indicated a direct effect of drought on premature senescence in June-grazed pastures. Drought indirectly in- 
creased senescence in July-grazed pastures by reducing herbage production, thereby increasing grazing pressure. Density of live stiff sunflower shoots declined by about $15 \%$ per $10 \mathrm{AUD} \cdot \mathrm{Mg}^{-1}$ increase in cumulative grazing pressure in both years when grazed in July (Fig. 4). Contrasts in premature senescence between June- and July-grazed stiff sunflower responses may have been related to differences in the amount and duration of photosynthetically active surface area before and after grazing. At similar levels of leaf area removal, stubble height was about 2.5 times greater in July, which may have resulted in a greater amount of remaining leaf area in July compared with June.

High levels of premature senescence likely limited vegetative reproduction because rhizome growth begins in mid-June and the distal ends of rhizomes do not enlarge into hibernacles until after mid-August. Declines in stiff sunflower populations corresponded to increasing levels of premature senescence regardless of the month in which pastures were grazed. Spring populations generally declined (Fig. 2) when more than $30 \%$ of the plants turned brown by mid-August during the previous year (Fig. 4).

Premature senescence also may have influenced defoliation patterns (Table 2) by altering the palatability of stiff sunflower plants. For example, when drought occurred in 1997 (Fig. 1), defoliation patterns were reversed with the highest percentage of plants grazed in lightly stocked pastures (Table 2). More than $50 \%$ of the plants in moderately and heavily stocked pastures turned brown by mid-August 1997, whereas plant senescence was uncommon in lightly stocked pastures (Fig. 4). Although senescence was not measured until August, some plants may have senesced before grazing treatments were applied in July. Senesced plants would be much less palatable and have a lower likelihood of being grazed.

\section{Management Considerations}

Uniform distribution of grazing rarely occurs in ranch-scale pastures in the Nebraska Sandhills because of topographic and vegetation heterogeneity and increasing distance to livestock water. The range of cumulative grazing pressures observed in our study pastures is likely to occur in most summer-grazed Sandhills pastures. Percentage of stiff sunflower plants grazed and levels of leaf area removal increase as cumulative grazing pressure increases. Cumulative grazing pressure generally increases in ranch-scale pastures as distance to water decreases. Consequently, stiff sunflower is most likely to occur on sites furthest from livestock water when pastures are grazed only during the summer. Plant heights and population densities were highest for nongrazed populations. Therefore, vigorous colonies of stiff sunflower are most likely to occur on Sandhills rangeland used primarily for dormant-season grazing.

Short-duration grazing treatments in this study resulted in stocking densities about 7 times greater than average densities in commonly used 4-pasture, deferred-rotation grazing systems at similar stocking rates. Short distances to livestock water and relatively high stocking densities in this study probably amplified the effects of stocking rate increasing the likelihood that all stiff sunflower colonies would be grazed. Regardless of stocking density, our study provides valid information on the relative importance of percentage of premature senescence, plants grazed, and leaf area removal for sustaining vigorous stiff sunflower populations.
Stiff sunflower has relatively low tolerance to grazing at traditional summer stocking rates before flowering. A critical level of $\geq 30 \%$ premature senescence in August can be used to determine when summer stocking rate reductions or growingseason deferment are needed in the subsequent year to sustain vigorous stiff sunflower populations. Critical levels of premature senescence are likely to occur in nondrought years when more than $60 \%$ of stiff sunflower plants have been grazed in June or July.

\section{Acknowledgments}

The authors wish to thank Erin Blankenship for statistical support; Sharon Holman for preparation of the manuscript; and Gordon Moeller, Justin McConkey, Andy Cullan, and April Allingham for technical assistance. Appreciation is also expressed for the thorough and helpful reviews provided by Marshall Haferkamp and 2 anonymous reviewers.

\section{Literature Cited}

Arthun, D., J. L. Holechek, J. D. Wallace, M. L. Galyean, M. Cardenas, and S. RAFIQUE. 1992. Forb and shrub influences on steer nitrogen retention. Journal of Range Management 45:133-136.

AtLAGić, J. 1996. Cytogenetic studies in hexaploid Helianthus species and their $F_{1}$ hybrids with cultivated sunflower, H. annus. Plant Breeding 115:257-260.

Cook, C. W. 1983. "Forbs" need proper ecological recognition. Rangelands 5: 217-220.

Cullan, A. P., P. E. Reece, and W. H. Schacht. 1999. Early-summer grazing effects on defoliation and tiller demography of prairie sandreed. Journal of Range Management 52:440-446.

Damhoureyeh, S. A., AND D. C. HaRtnett. 2002. Variation in grazing tolerance among three tallgrass prairie plant species. American Journal of Botany 89: 1634-1643.

Dickinson, J. A., AND M. J. McKone. 1992. Insect floral visitors to four species of tallgrass prairie composite (Asteraceae: Heliantheae). Prairie Naturalist 24:159174.

Frankland, F., and T. Nelson. 2003. Impacts of white-tailed deer on spring wildflowers in Illinois, USA. Natural Areas Journal 23:341-348.

Great Plains flora Association. 1986. Flora of the Great Plains. Lawrence, KS: University Press of Kansas. 1392 p.

Gronemeyer, P. A., B. J. Dilger, J. L. Bouzat, and K. N. Paige. 1997. The effects of herbivory on paternal fitness in scarlet gilia: better moms also make better pops. American Naturalist 150:592-602.

HARTNETT, D. C. 1990. Size-dependent allocation to sexual and vegetative reproduction in four clonal composites. Oecologia 4:254-259.

HaRTNET, D. C. 1996. Effects of bison grazing, fire, and topography on floristic diversity in tallgrass prairie. Journal of Range Management 49:413-420.

Hickman, K. R., AND D. C. HaRtNetr. 2002. Effects of grazing intensity on growth, reproduction, and abundance of three palatable forbs in Kansas tallgrass prairie. Plant Ecology 159:23-33.

Hodgkinson, K. C. 1980. Frequency and extent of defoliation of herbaceous plants by sheep in a foothill range community in northern Utah. Journal of Range Management 33:164-169.

Hoehne, O. E., D. C. Clanton, and C. L. Streeter. 1968. Chemical composition and in vitro digestibility of forbs consumed by cattle grazing native range. Journal of Range Management 21:5-7.

HOLECHEK, J. L. 1984. Comparative contribution of grasses, forbs, and shrubs to the nutrition of range ungulates. Rangelands 6:261-263.

INOUYE, D. W. 1982. The consequence of herbivory: a mixed blessing for Jurinea mollis (Asteraceae). Oikos 39:269-272.

JULANDER, 0. 1968. Effect of clipping on herbage and flower stalk production of three summer range forbs. Journal of Range Management 21:74-79. 
Kawano, S. 1985. Life history characteristics of temperate woodland plants in Japan. In: J. White [ed.]. The population structure of vegetation. Dordrecht, The Netherlands: Dr W. Junk Publishers. p 515-549.

Laycock, W. A., AND P. W. ConRad. 1969. How time and intensity of clipping affect tall bluebell. Journal of Range Management 22:299-303.

Nichols, J. T., AND P. N. Jensen. 1998. Range judging handbook and contest guide for Nebraska. Cooperative Extension EC98-150-F. Lincoln, NE: University of Nebraska.

NoRTHUP, B. K. 1993. Utilization of native forages of the Nebraska Sandhills by yearling cattle [PhD dissertation]. Lincoln, NE: University of Nebraska. $328 \mathrm{p}$.

PIEPER, R. D., AND R. F. BECK. 1980. Importance of forbs on southwestern ranges. Rangelands 2:35-36.
RatKowSKY, D. A. 1990. Handbook of nonlinear regression models. New York, NY: Marcel Dekker, Inc.

Reichman, O. J., And S. C. Smith. 1991. Responses to simulated leaf and root herbivory by a biennial, Tragopogon dubius. Ecology 72:116-124.

SAS. 2002. SAS Online Doc®. Version 8. Cary, NC: SAS Institute Inc.

Verburg, R. W., KWant, R., and M. J. A. Werger. 1996. The effect of plant size on vegetative reproduction in a pseudo-annual. Vegetatio 125:185-192.

Vermeire, L. T., and R. L. Gillen. 2000. Western ragweed effects on herbaceous standing crop in Great Plains grasslands. Journal of Range Management 53:335-341.

WESTLEY, L. C. 1993. The effect of inflorescence bud removal on tuber production in Helianthus tuberosus L. (Asteraceae). Ecology 74:2136-2144. 